\title{
Interfaces
}

INTERFACES Image Texte Language

$45 \mid 2021$

Jeux de formats (1)

\section{Interview with artist Peter Sacks}

\section{Donald Friedman}

\section{(2) OpenEdition}

\section{Journals}

\section{Electronic version}

URL: https://journals.openedition.org/interfaces/2964

DOI: 10.4000/interfaces.2964

ISSN: 2647-6754

\section{Publisher:}

Université de Bourgogne, Université de Paris, College of the Holy Cross

\section{Printed version}

Date of publication: 12 July 2021

ISSN: 1164-6225

\section{Electronic reference}

Donald Friedman, "Interview with artist Peter Sacks", Interfaces [Online], 45 | 2021, Online since 12 July 2021, connection on 15 September 2021. URL: http://journals.openedition.org/interfaces/2964 ; DOl: https://doi.org/10.4000/interfaces.2964

This text was automatically generated on 15 September 2021.

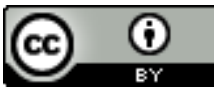

Les contenus de la revue Interfaces sont mis à disposition selon les termes de la Licence Creative Commons Attribution 4.0 International. 


\title{
Interview with artist Peter Sacks
}

\author{
Donald Friedman
}

Figure 1. Peter Sacks, Mare Incognitum, 60x150, 2020, Baltimore Museum of Art.

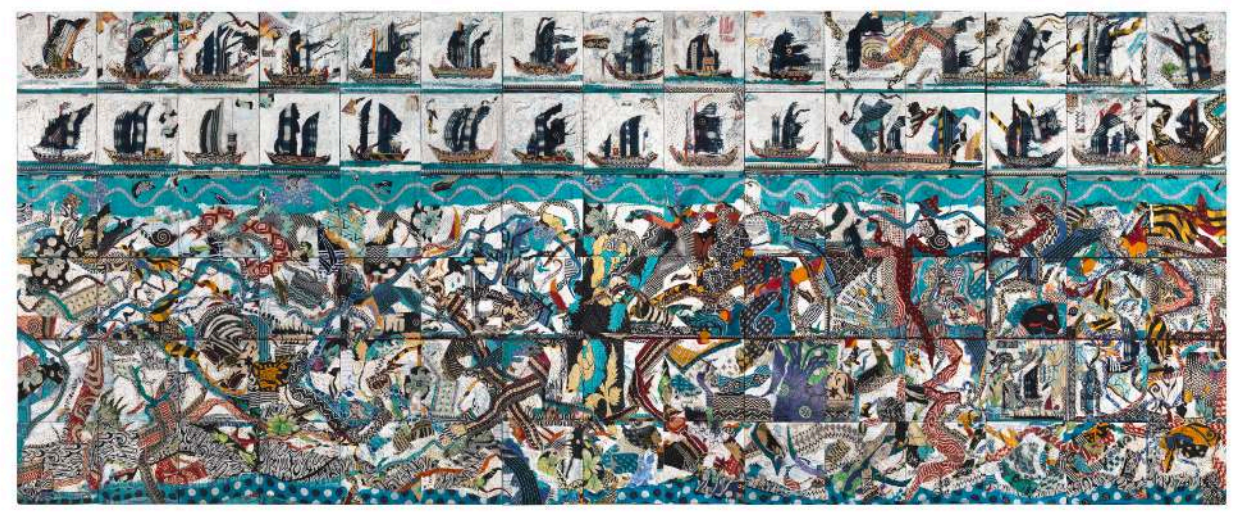

(c) Peter Sacks.

\section{Presentation}

1 Link to the interview : Peter Sacks Joins the Greats - YouTube

2 You, dear Interfaces reader, will shortly be the first to witness the video of a historic moment. Back around 2001, Peter Sacks, a fully formed successful poet and Harvard professor, who had only a year or two earlier gotten the urge to pick up a brush, explained on camera what had led him from text to image, to reframe his creative ideas in a visual expression, and then to move from small to large format. In the interview, Sacks lays out the vision which in a mere two decades will have the world hailing him as an artistic phenomenon. Today his works have been purchased by the Metropolitan Museum of Art, and Baltimore Museum of Art, and he is represented by premier galleries in New York and Paris. The interview was preparatory to Sacks' inclusion in my book, The Writer's Brush: Paintings, Drawings, and Sculpture by Writers. Neither he nor I 
could have imagined then that he would join the minority of its hundreds of subjects whose visual art equals or exceeds their writing, that Sacks would join the company of Arp, Barlach, Blake, Fromentin, Jones, Kokoschka, Lewis, Rossetti, and Strindberg. Yet, looking at the video now, one can see that it's all there: the talent, the brilliantly articulated vision, the passion bordering on obsession that will carry him through.

3 A Peter Sacks' painting is fashioned in layers. Besides paint, the layers are comprised of musical scores by Beethoven, Bach, and Mahler, literary and political texts, and whatever materials are at hand, including fabrics and a variety of scrounged items. Importantly, the layers contain both allusions to world history-- and to Sacks' own biography. His visual expressions reflect the sensibility that J.M. Coetzee found in his poetry: "a poet whose sense of history lies deep in his bones..." It is the sensibility that his wife, poet Jorie Graham, described to New Yorker reporter Joshua Rothman, as informed by his life as "the émigré African, the diasporic Jew."1

Despite the vibrant, visually engaging surfaces of his paintings, much of what he creates is hidden from view. The concealment serves at least two purposes: it creates a landscape of textures that will shape the heavy impasto that is overlayed, and it allows Sacks to excavate images by selectively removing the cover work - sometimes with a fire - to reveal what he's buried. Demonstrating his process for Rothman Sacks set fire to a piece of linen he'd glued to a canvas leaving behind part of the fabric and altered materials. Rothman quotes him at that moment: "Ultimately, the reason I'm not writing poems is because I can't express whatever just happened there."

Sacks had not determined to abandon poetry in favor of expression in visual format at the time of this interview. But that life-altering choice can be divined from the greater joy he was finding in painting; however, he ascribed it initially to the power of silence and to his belief that the visual better captured a sense of duration.

It was watching a lunar eclipse, said Sacks, that led him out of words and into paint : "As that gradual diminution and then reemergence of light occurred in complete silence, it was as if the materiality of what I was witnessing was more palpable because of the silence." What he wanted, he said, was "to be there as if I weren't there." He realized that "speech is a way of presenting oneself through voice, immediately," so

by not speaking I think one can entertain the imagining of what it might be like to not be there. So somehow I came back and just started doing the most minute little sequence of sketches of this experience because I wanted to capture duration. And because the visual world doesn't score its tempo. You stand in front of a painting and you could stand there for three years if you wanted to or three minutes. There's nothing in the painting saying this is a five-minute experience." 


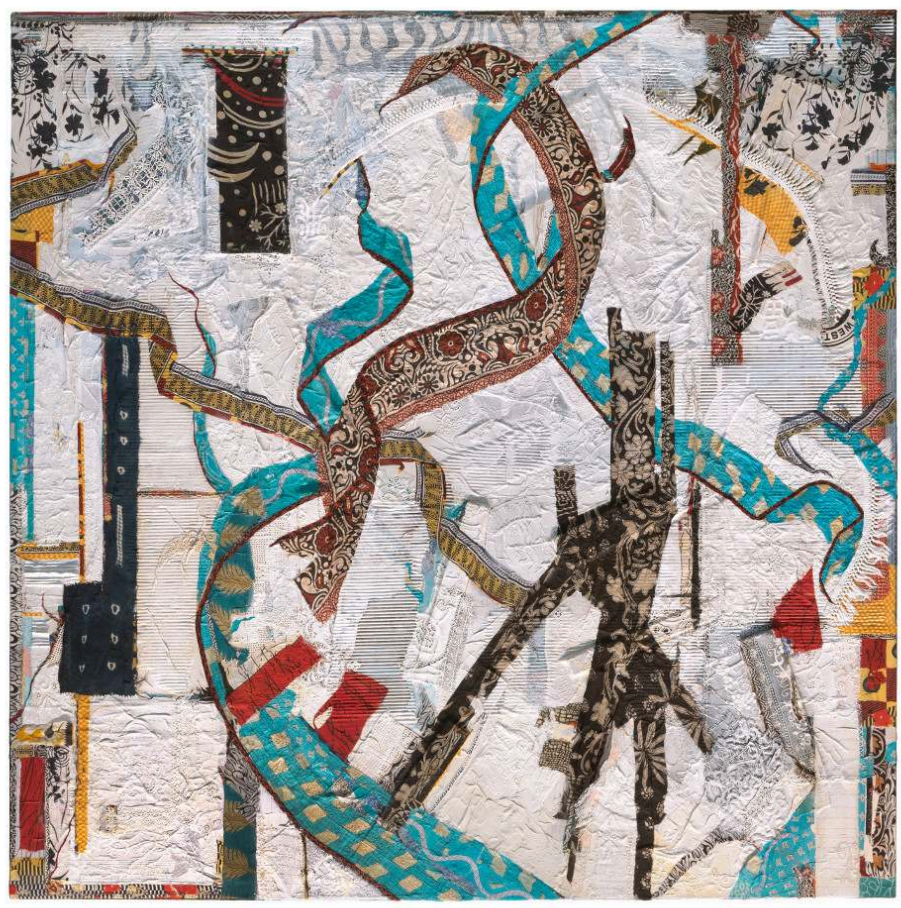

(c) Peter Sacks.

7 Although he'd begun with small works, ink drawings and pastels in notebooks and sketchbooks, within a few years he was painting the immediately engaging museumscale canvases he shows and discusses in this interview. The breakthrough for Sacks occurred, he said, when he had made a simple rectangle and was painting within its borders:

"What happened was that I came in one evening I think and added two tabs on the left-hand side of this rectangle and realized that I had created what looked like hinges, so that the rectangle just by virtue of that abstract addition became also now a door.... And then the whole notion of what a door was, opened, literally like a door. Then the question was, well, are you looking at the surface of a door, or are you looking at a doorway, or what does this door open into?"

Exploring the answer to that question, Sacks began to produce

"door after door after door and I did about thirty-three doors and they're all thirtysix by sixty inches so they are pretty isomorphic. ... One of the things that I was doing was finding that this was a way to allow parts of my life to get into the work that hadn't been given the same kind of expression in the poems."

9 An intensely private man given to long solitary walks - he speaks of twenty to thirty mile walks through the night in the desolate landscape of the Texas-Mexican border coincident with his first exploration into layering images; he'd begun by taking snapshots which he covered with Wite Out correction fluid until nothing was visible. Sacks not only kept his life out of his art his impulse was to let his art remain unseen. "The genesis of it all," he told me, "was completely without the sense that this was going to be seen or accepted as art." To Rothman he spoke approvingly of ancient artists and craftsmen who "wouldn't just bury their work-they'd seal it up and make it impossible for others to find it." 
Sacks was born in 1950 in Port Elizabeth, South Africa. Like his physician father, he planned a medical career but a "mind-opening" visit to racially torn Detroit in the 1960s resulted in his returning home to study political science and philosophy and becoming involved in the antiapartheid movement. He fell in love with poetry while a scholarship student at Princeton. After graduating in 1973, Sacks was a Rhodes Scholar at Oxford. He received his M. Phil. there in 1976 and a Ph.D. from Yale in 1980. A professor of English Literature at Harvard, Sacks is married to poet Jorie Graham. His books of poetry include In These Mountains (1986), Promised Lands (1990), Natal Command (1997), O Wheel (2000) and Necessity (2002).

\section{Video transcription}

Figure 3. Peter Sacks, Report from the Besieged City, 3, 2014-2018, Artist's collection.
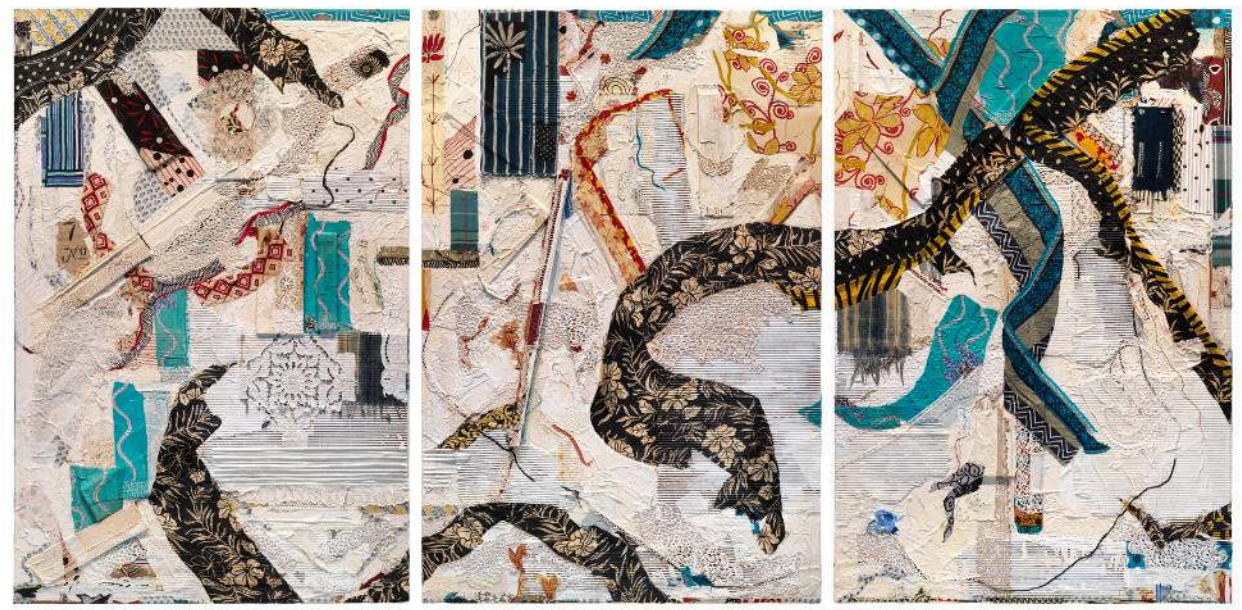

(c) Peter Sacks.

Link to the interview : Peter Sacks Joins the Greats - YouTube

Peter Sacks was a poet and professor when I interviewed him in 2001, two and a half years after he had picked up a paintbrush for the first time. Today his work is in the Metropolitan Museum of Art, the Museum of Modern Art and Boston's Museum of Fine Arts. Here is what Sacks had to say at the cusp of his transformation.

One of the triggers was just standing on a field, watching a lunar eclipse. And as that gradual diminution, and then re-emergence of light occurred in complete silence, it was as if the materiality of what I was witnessing was more palpable because of the silence. And so to introduce words seem to be coming at this experience in a way that was going to reduce the sheer substance of what it was that I was witnessing. And I felt drawn to just remaining silently present. And somehow for me paint because it's part of the world itself, seems more embedded in the cosmos than language. And that's been a lot of the draw to making paintings subsequently.

\section{A painting becomes a doorway}

The breakthrough for me with moving into painting I thought occurred when I started making a rectangle, which was, acknowledgedly abstract, and relatively dark. And for 
an entire congerie of reasons, which I'm still exploring, at one moment, after hours of working on the surface, and remaining roughly within the rectangle, the border of the canvas was left unpainted so that it was white. I came in one evening, I think, and added two tabs on the left-hand side of this rectangle, and realized that I had created what looked like hinges, so that the rectangle, just by virtue of that, you would say abstract addition of two rectangles on the left of it, which could be read as hinges, became also now a door. And so that it moved, just by that addition, from being an abstract representation, to a fairly legible depiction of a door. And then the whole notion of what a door was opened, literally, like a door. Because then the question was, "Well, are you looking at the surface of the door? Or are you looking at a doorway? or What does this door open onto? So what is your sense of what's behind the painting? And how does it act as a threshold between us and this other realm that it might give access to?"

This is a door. This one, I was fascinated by trying to complicate my access to the door, as if it was as alluring as it was blocking. On the back, I copied out the Kafka story "Before the Law," which is about the man who sits for his entire life at a doorway. And on the other side of the doorway is "the law," and the illumination of the law so that he will finally understand what the great law is. But he's blocked, and he has to sit there his entire life. And so this idea of capturing the back of this painting - I just copied it out by longhand - and then a photo of Kafka, and then painting it so that it has this sense of what's behind it.

I ended up doing door after door after door, and I did about 33 doors. And they're all 36 by 60 inches. And so they're pretty isomorphic. But the colors vary greatly. The textures vary greatly. And one of the things that I was doing was finding that this was a way to allow parts of my life to get into the work that hadn't been given the same kind of expression in the poems.

\section{Hidden voices pressing out}

I was listening to music while I was making these. And in fact, at some point, I was applying the paint in rhythm to the music, I was listening to Beethoven sonatas. And it was as if for every brushstroke, there could be a note. Then what happened is I went and got the actual score of the sonata, and cut little bits and pieces of it, and embedded phrases of it into the actual canvas. And sometimes I would allow a tiny bit of it to remain perceptible. And other times I'd just paint over it. But it started building up a private archive for me of musical reference. I would sometimes copy out poems longhand, onto bits of paper and put that in against the canvas and then paint over that. So that I would know that somehow, buried in there, was a poem of John Donne, or a stanza of Wallace Stevens, and there would be some strange pressure exerted, from my sense of what was behind the surface of the paint, thinking that there was a voice back there or a music back there. And I would, I think, start painting as if I was trying to give form to the emotion that that poem might have for me. And in some cases, I was very aware of what the text was. 


\section{Image versus word}

18 I know that there's just a realm of experience that seems to be more adherent to the visual than to the verbal. And it's very hard for me to break this down, because my poems are increasingly interested in coming up against the inexpressible, and the margin of silence. And I feel the words almost hitting up against the unspoken and recoiling and pushing back again, whether it's just one sense of what time is or what mortality is, or what historical atrocity is - something that's unspeakable - but that the language impacts and throws itself against, and so there is a deep relation in the exploration in both media of the otherwise inexpressible, something that only that poem or that painting can make present in the world. And I don't feel that one is more. I think it's probably a division of labor in some ways.

But I know that my imagination is highly visual. And so that the experience of concentration given to me by certain paintings is an experience that I've tried to recapture in poems, either by close attention to visual detail. Or by just finding a linguistic way to get as close as I can to a certain saturation that I love in paintings

\section{Pleasure in painting}

20 I have to say that I'm finding more satisfaction at the moment, just sheer satisfaction, in the visual realm. And I think it's because of the physicality of the medium. And the sense of just working material allows more of my body into the space of making. Whereas the page is..it's remorselessly alien to the human body, domain. And to get one's words to have the kind of physicality is, is something that's wracking, and excruciating, and it's terrifically satisfying when it's happening. But when it's not, there's not the same place for free play, that I've been finding in the visual where I can just keep moving the stuff around. And words are so insistent, and they have their constituencies in meaning. And so it's as if you've declared yourself, you know, with each next on word, whereas there's a way to remain amorphous, at least semantically, you know, while working the paint, and I just, just love it.

\section{An epiphany in the wilderness}

What spawned this preceded the making of the door, the sequence. And what happened there was, since the doors were the first canvases I made, I had begun on smaller pieces before that. And I had been out in this area of West Texas near the Mexican border in a very isolated place, and was taking these very long walks, sort of 20-30 mile walks. And I got one of those little disposable cameras and took snapshots of the landscape, you know, over a sequence of weeks, and got them back and they were terrible. And I, I wasn't planning to make any visual stuff out there. I was out there to write for a couple of months. And all I had was a little bottle of Wite Out. And I started whiting out these photographs until there was absolutely nothing that one could see. Except that I liked the whiteness because it had marks and it had a little impasto. And it was absurdly painstaking, because I was using this little you know, those little Wite Out brushes. And I realized I was making white paintings, and I called them "erasures." And there was nothing visible on them, except the little ridges and bits of rhythm and texture. But I loved it. And it was deeply satisfying. And I did a lot of these. And then I would make 
them into triptychs, I'd put one, two, three, as if they were kind of altarpiece of erasure or they had a narrative of erasure. And then I thought, "Well, I've got to get some color into this after a while." But again, I didn't have paints, I didn't have supplies, I didn't have anything. So I started with a blue felt tip pen, and I started introducing blue. And then I got a red felt tip pen and I started mingling them, and they made it a dark magenta black. And I loved the blackness of them. So I was making all of these tiny things the size of the snapshot, and then making sequences of these. That's what triggered me to say, "Okay, well, what if we started doing these big?" And so the first things I was doing was just making these large rectangles of, of usually dark, some of them were just completely red, some of them were completely black. And then I started flecking them up and building up the texture with many colors. And then the door, you know, with the hinge idea. It's almost never been starting with an actual idea. Except once I got into the sequence of doors, I knew that the format would somehow produce another door. But then when that stopped, then I started cold and shifted the dimensions. And then it was really a matter of seeing what emerged in the act of making.

\section{Before things got big}

Figure 4. Peter Sacks, Township 17, 7x7, 2014-2018, Artist's collection.

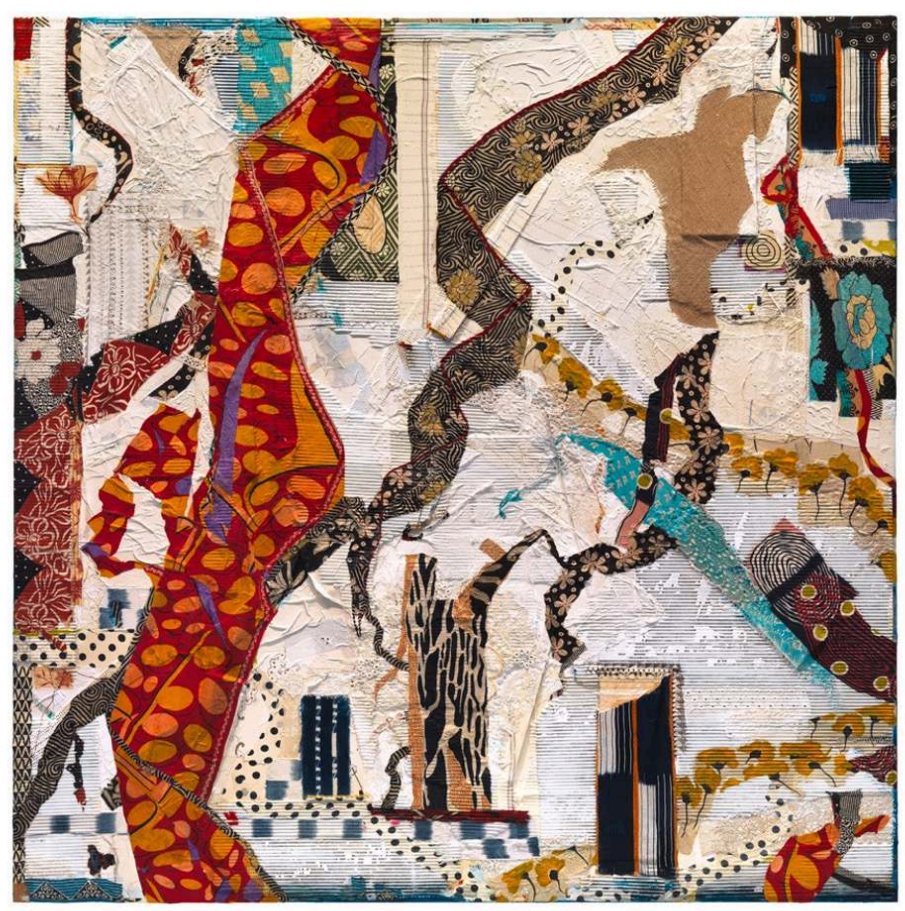

(c) Peter Sacks.

These are notebooks and they are just full of the crossover between drawing... [crosstalk] This corresponds to the time... Yeah, this is December of 99... [crosstalk] There's a variety of stuff, but I mean, this turns out to have been an image that I saw of people trying to break down a door. And it was around the time of civil war in the Balkans. And so then I would move to trying to make a poem. And it turns out that the 
language here, and this is just the beginning of what might be a poem or not. But it just says, "You break the door, you take lives calling out elsewhere, you crowd against, say," etc, etc. So that there's an attempt to work with this in both mediums. And then - I'll just as I page through - I had a sense of a looming figure that was coming through a half door. So there would be these ways of going at things, you know, that go back and forth between language and... But what I'm trying to get to here is a sense of how history comes in. I was reading a book about the fall of Berlin. And so imagine the sketch of people coming in having to pass your access to a city having to be via a fallen person, but then I could make these more specific so that they could include let's say paintings that I had discovered. At the time that I was interested in doors, I found this Goya of a madman who'd been put into stocks. So I just thought I'd make an ink sketch of it. Because what the door could contain and entrap and getting involved in it, I felt I was myself somehow starting to portray myself as if in the door.

\section{Capturing the underworld}

But what happened is that after the doors, I did some canvases that were pretty much all over dark, illegible, except they had a certain richness of consistency and a certain suggestiveness. And I am interested in trying to paint states of being, rather than objects and elements, rather than objects, so say air or earth or fire or water. And so that there's many that come out of a sense of the night sky, or of what might be under the surface of the earth. How you paint a slab, let's say, of the underground, of the underworld. And this began to fascinate me, the attempt to paint the underworld is what then led me to build this up. And there's trace elements here rhythmically, in the way the paint is applied, that suggest tributaries, or dendrites - some kind of primal domain, that could as much be the night sky as it could be the underworld, and certain rhythms that could recur through it. But what happened is that as I dwelt in this area was that I wanted to capture something greater. And this turned out, as I put it together, to allow these shafts to be introduced, as if there was a capacity for illumination. Or, since if you dwell on something that is dark, what is the counter impulse? And where does it come from in the psyche or in the planet itself? And I wanted to somehow give, to do justice to that polarity. And the eye has to dwell in it for quite a while before the colors emerge the way you would be accustomed to the night or accustomed to a cave. And this underworld place in which shafts of possible light existed, but might be doorways as well, led to my sense that I was really trying to paint the world of Euridice or of Orpheus. And so this became a kind of underworld, with narrative or with myth below it. And, however one reads it - I don't want to overdetermine the painting, but I did want there to be this tension between luminosity and darkness, between being trapped and being led out of confinement and egress of things being vertical, or things being on a slant, being able to transgress the frame of the painting.

\section{Intuiting format and content}



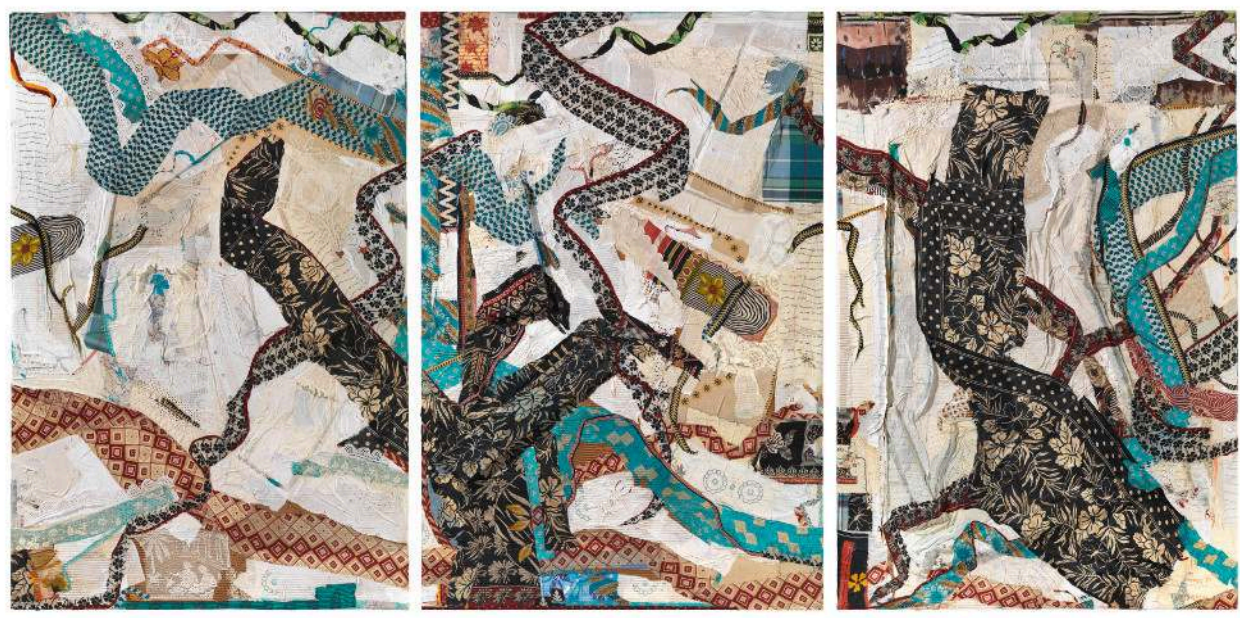

(c) Peter Sacks.

Very many of these begin with one panel, and then if the subject seems to be expanding, I'll add a panel. And then sometimes it will be on the right, sometimes it'll be on the left, sometimes I'll reverse them. In some instances, I have a pretty strong intuition that it's going to be a three-panel painting.

I think I was interested in high contrast in this one...

You know, I'd paint for four or five, six hours, seven hours, take a quick break, paint for another three hours, sometimes paint, you know, well into the night, and music is usually playing. I know this one was accompanied by Mahler's Second, which is, you know, an enormously long thing. It's called The Resurrection Symphony. And it's got very strong contrasts within it.

Because music, the music that I was listening to was not accompanied by words, its significance was in a way up for grabs, in terms of, you know, just traditional notions of, "Okay, so what is the meaning of this music?" And so one was prompted to find just gestural responses to it, that were as inarticulate verbally as, say, my response to the lunar eclipse. And yet a way of witnessing the music, and making that witness physical and embodying my response to it so that after having painted a door, that corresponded, let's say, to my having listened to the Waldstein Sonata, over and over, I felt that the sonata was somehow embedded now in that door. Or if it was a piece of Mahler or Bach was very important; because the sense of structure that gradually emerged was influenced by notions of counterpoint and antiphony and fugue. And so, yeah, the synesthetic response was really quite - I mean, I'd feel it in my arms very much, and in my shoulders, the music, and it was thrilling. Very mysterious.

\section{Painting for himself}

I thought for sure, nobody was gonna see these things. And I didn't know if I could make anything that was going to be worth seeing. Still don't. That's, you know, ultimately not going to be up to me. But the genesis of it all, was completely without the sense that this was going to be seen or be accepted as art. 


\section{NOTES}

1. The New Yorker, March 10, 2019, Profiles, An Artist's Archeology of the Mind, interview by Joshua Rothman. Available at An Artist's Archeology of the Mind I The New Yorker.

\section{AUTHOR}

\section{DONALD FRIEDMAN}

Donald Friedman, a novelist, essayist, sometime lawyer, but never a scholar, somehow produced the internationally acclaimed The Writer's Brush: Paintings, Drawings, and Sculpture by Writers. That book brought together the visual art of more than 200 of the world's great writers. To celebrate its publication, he planned a modest exhibition of writer-art which, with the assistance of John Wronoski, antiquarian bookseller and art dealer, was enlarged to include dozens of poets and writers somehow omitted from the book, and became a museum-scale show (https:// donaldfriedman.com/books/the-writers-brush-the-exhibition/). Along the way to the book and the exhibition, Friedman interviewed a number of writer-artists on camera. Excerpts of those interviews are being posted on Interfaces' website, accompanied by transcripts and introductions. For Interfaces contributors and friends interested in acquiring copies of The Writer's Brush direct from the author at a deep discount, please contact him through his website, https://donaldfriedman.com/books/the-writers-brush/ 